\title{
EFEK ANTIBAKTERI SABUN MANDI CAIR EKSTRAK BUAH KAPULAGA TERHADAP Staphylococcus aureus
}

\section{ANTIBACTERIAL EFFECTS OF LIQUID SOAP KAPULAGA FRUIT EXTRACT AGAINST Staphylococcus aureus}

\author{
Yahdian Rasyadi ${ }^{1 *}$, Revi Yenti ${ }^{1}$, Aulia Putri Jasril ${ }^{1}$ \\ ${ }^{1}$ Fakultas Farmasi, Universitas Perintis Indonesia, Padang
}

Naskah diterima tanggal 18 November 2020

\begin{abstract}
In human skin there are many bacteria, for example Staphylococcus aureus. Staphylococcus aureus infection is characterized by tissue damage followed by an abscess. Soap serves to clean the skin from dirt and bacteria. Ethanol Extract Cardamom fruit which has been formulated into liquid bath soap is thought to have antibacterial properties. This study aims to test the antibacterial activity of liquid bath soap containing cardamom (Amomum compactum Sol. Ex Maton) F1, F2, and $\mathrm{F} 3$ extracts with $2 \%, 4 \%$, and $6 \%$ ethanol extracts of cardamom fruit against Staphylococcus aureus bacteria. The antibacterial test of liquid soap was carried out against Staphylococcus aureus bacteria using the agar diffusion method. The results of the liquid soap antibacterial activity test showed that the average inhibition diameter was F1 $(22.33 \pm 0.85 \mathrm{~mm}), F 2(24.63 \pm 0.58 \mathrm{~mm})$ and F3 $(25.80$ $\pm 0.17 \mathrm{~mm}$ ). All formulas of cardamom fruit ethanol extract liquid bath soap have strong antibacterial activity against Staphylococcus aureus growth inhibition.
\end{abstract}

Keywords: liquid bath soap; ethanol extract; cardamom fruit; Staphylococcus aureus

\begin{abstract}
ABSTRAK
Di dalam kulit manusia terdapat banyak bakteri, contohnya Staphylococcus aureus. Infeksi Staphylococcus aureus ditandai dengan kerusakan jaringan dan diikuti abses. Sabun berfungsi untuk membersihkan kulit dari kotoran maupun bakteri. Ekstrak etanol buah kapulaga yang telah diformulasi menjadi sabun mandi cair diduga memiliki khasiat antibakteri. Penelitian ini bertujuan untuk menguji aktivitas antibakteri sabun mandi cair yang mengandung ekstrak buah kapulaga (Amomum compactum Sol. Ex Maton) F1, F2, dan F3 dengan kandungan ekstrak etanol buah kapulaga masing-masingnya $2 \%, 4 \%$, dan $6 \%$ terhadap bakteri Staphylococcus aureus. Uji antibakteri sabun mandi cair dilakukan terhadap bakteri Staphylococcus aureus dengan metode difusi agar. Hasil uji aktivitas antibakteri sabun cair menunjukkan diameter hambat rata-rata $F 1(22,33 \pm 0,85$ $\mathrm{mm})$, F2 $(24,63 \pm 0,58 \mathrm{~mm})$ dan F3 $(25,80 \pm 0,17 \mathrm{~mm})$. Semua formula sabun mandi cair ekstrak etanol buah kapulaga memiliki aktivitas antibakteri tergolong kategori kuat terhadap penghambatan pertumbuhan Staphylococcus aureus.
\end{abstract}

Kata Kunci: sabun mandi cair; ekstrak etanol; buah kapulaga; Staphylococcus aureus

\section{PENDAHULUAN}

Kulit adalah suatu organ pembungkus seluruh permukaan luar tubuh, merupakan organ terberat dan terbesar dari tubuh. Seluruh kulit beratnya sekitar $16 \%$ berat tubuh, pada orang dewasa sekitar $2,7-3,6 \mathrm{~kg}$ dan luasnya sekitar $1,5-1,9 \mathrm{~m}^{2}$ (Kalangi, 2014). Kulit menutupi permukaan tubuh dan memiliki fungsi utama

Alamat korespondensi :

yahdianrasyadi@gmail.com sebagai pelindung dari berbagai macam gangguan dan rangsangan luar. Kulit merupakan pertahanan utama terhadap bakteri dan apabila kulit tidak lagi utuh, maka menjadi sangat rentan terhadap infeksi. Infeksi disebabkan oleh bakteri, virus, jamur, protozoa dan beberapa kelompok minor lain (Dimpudus et al, 2017)

Untuk membersihkan kulit dari gangguan kuman, jamur dan bakteri dapat digunakan sabun pembersih kulit. Sabun dapat berbentuk krim, padatan, batangan, bubuk dan bentuk cair 
(Widyasanti et al, 2016). Sabun mandi cair memiliki kelebihan antara lain proses pembuatannya relatif lebih mudah, biaya produksinya yang murah, serta mudah penyimpanan dan penggunaannya sehingga, sabun tidak mudah rusak (Putra et al, 2016).

Sabun secara umum didefinisikan sebagai garam alkali dari asam lemak rantai panjang. Saat lemak atau minyak disaponifikasi terbentuk garam natrium atau kalium dari asam lemak rantai panjang yang disebut sabun. Sabun dihasilkan dari dua bahan utama yaitu alkali dan trigliserida (lemak atau minyak) (Yulianti et al, 2015). Sabun berfungsi untuk membersihkan kulit baik dari kotoran maupun bakteri. Pada kulit manusia terdapat banyak bakteri, salah satunya adalah bakteri Staphylococcus aureus. Bakteri Staphylococcus aureus merupakan bakteri yang paling sering ditemukan di kulit (Rosalina et al, 2010) . Bakteri ini juga dapat kita temukan di udara dan lingkungan sekitar. Infeksi yang disebabkan oleh bakteri Staphylococcus aureus ditandai dengan adanya kerusakan jaringan dan diikuti dengan abses bernanah. Beberapa penyakit infeksi yang juga disebabkan oleh Staphylococcus aureus antara lain bisul, impetigo, dan infeksi luka (Ryan et al., 1994).

Dewasa ini, sabun mandi antibakteri sangat diminati oleh masyarakat. Hal ini disebabkan karena dipercaya dapat membersihkan kulit, juga dapat mengobati dan atau mencegah penyakit yang disebabkan oleh bakteri. Triclocarban merupakan zat antibakteri yang paling banyak digunakan dalam sabun mandi padat, namun menurut Badan Obat dan Makanan Amerika Serikat (FDA) jika digunakan dalam jangka panjang dapat menyebabkan resistensi bakteri terhadap antibiotik. Salah satu cara menghindari efek samping yang ditimbulkan oleh triclocarban adalah penggunaan antibakteri dari bahan alam sebagai alternatif pengganti triclocarban (Sukawaty et al, 2016).

Indonesia merupakan negara kaya dengan tumbuhan yang berkhasiat untuk obat. Penggunaan tumbuhan sebagai obat telah dikenal sejak zaman nenek moyang dan telah diwariskan secara turun-temurun. Banyak jenis bahan alam mengandung senyawa yang bersifat antibakteri. Sejumlah bahan alam mengandung senyawa bersifat bakterisidal (pembunuh bakteri), dan bakteristatik (penghambat pertumbuhan bakteri)(Putri, et al, 2017). Salah satu tanaman obat diduga memiliki sifat sebagai antibakteri, sehingga dapat dimanfaatkan sebagai antibakteri alami, adalah kapulaga (Amomum compactum Sol. ex Maton) (Sukandar et al., 2016).

Buah kapulaga mengandung minyak atsiri yang terdiri dari sineol, terpineol, dan borneol. Selain itu buah kapulaga juga banyak mengandung saponin, flavonoid, senyawasenyawa polifenol, pati, gula, lemak, protein dan silikat (Deviarny et al, 2015).

Berdasarkan hasil penelitian Komala et al, (2020) menyatakan bahwa ekstrak buah kapulaga dengan metode maserasi pada konsentrasi $7,5 \%$ efektif sebagai antimikroba dalam menghambat Streptococcus pyogenes. Hasil penelitian yang telah dilakukan oleh Budiarti et al, (2013) menunjukkan bahwa ekstrak metanol, n-heksana, etil asetat, n-butanol buah kapulaga dengan konsentrasi $0,25 \%, 0,5 \%$ dan $1,0 \%$ mempunyai aktivitas sebagai antibakteri terhadap Staphylococcus aureus, Streptococcus mutans dan Escherichia coli.

Ekstrak etanol buah kapulaga telah diformulasi dalam sediaan sabun mandi cair dalam empat formula yaitu F0 (mengandung ekstrak buah kapulaga 0\%), F1 (mengandung ekstrak buah kapulaga 2\%), F2 (mengandung ekstrak buah kapulaga $4 \%$ ), dan F3 (mengandung ekstrak buah kapulaga 6\%), stabil secara fisika selama penyimpanan enam minggu dan memenuhi syarat sediaan sabun mandi cair (Rasyadi et al, 2019b).

Tujuan dari penelitian ini adalah untuk melihat apakah sediaan sabun mandi cair ekstrak etanol buah kapulaga (Amomum compactum Sol. ex Maton) memiliki aktivitas antibakteri terhadap bakteri Staphylococcus aureus. Penelitian ini merupakan lanjutan pengujian aktivitas antibakteri dari hasil formulasi sabun mandi cair pada penelitian sebelumnya (Rasyadi et al, 2019b).

\section{METODE PENELITIAN}

Alat

Alat yang digunakan yaitu, Laminar Air Flow (Biobase), autoklaf (All American), Vortex mixer (Corning) dan alat standar laboratorium lainnya.

\section{Bahan}

Bahan yang digunakan yaitu Ekstrak Etanol Buah Kapulaga C1 (ekstrak buah kapulaga 2\%), C2 (ekstrak buah kapulaga 4\%), C3 (ekstrak buah kapulaga 6\%), C- (Dimethyl Sulfoxide (DMSO)), sabun mandi cair ekstrak etanol buah kapulaga yaitu FO (mengandung ekstrak buah kapulaga 0\%), F1 (mengandung ekstrak buah kapulaga 2\%), F2 (mengandung ekstrak buah kapulaga $4 \%$ ), dan F3 (mengandung ekstrak buah kapulaga 6\%), P (sediaan sabun mandi cair pembanding merek $D \otimes)(e k s t r a k$ dan formula sabun mandi cair ekstrak etanol buah kapulaga didapat dari penelitian Rasyadi et al, (2019b)), bakteri Staphylococcus aureus (diperoleh dari Fakultas Kedokteran UNAND), media muller Hinton agar (Merck), etanol 96\% (Brataco), larutan $\mathrm{NaCl}$ 
fisiologis 0,9\% (Widarta Bakti), larutan Mc Farland $0,5 \%$.

\section{Metode}

\section{Pembuatan Media}

Media dibuat dengan melarutkan 3,8 gram Muller Hinton Agar dalam 100 ml aquadest dalam labu erlemeyer digoyang-goyang selama 15 menit dan dipanaskan sampai mendidih sambil diaduk sampai larut sempurna. Erlemeyer di tutup dengan kapas yang dibungkus dengan kain kasa, kemudian disterilkan dalam autoklaf pada suhu $121^{\circ} \mathrm{C}$ selama 15 menit. Dibiarkan dingin sampai suhu $45-50^{\circ} \mathrm{C}$, lalu dituangkan ke dalam cawan petri yang telah disterilkan (Utomo et al., 2018; Rasyadi et al, 2019a).

\section{Pembuatan Suspensi Bakteri Uji}

Koloni bakteri disuspensikan dalam larutan $\mathrm{NaCl}$ fisiologis steril dalam tabung reaksi steril dan dihomogenkan dengan vortex kemudian diukur kekeruhannya dengan membandingkan dengan standar kekeruhan larutan Mc.Farland (Aristyawan et al, 2018; Rasyadi et al, 2019a).

\section{Pengujian Aktivitas Antibakteri Ekstrak Buah Kapulaga (Amomum compactum Sol. ex Maton)}

Sebanyak $10 \mathrm{~mL}$ medium MHA dimasukkan kedalam cawan petri ditambahkan 1 $\mathrm{mL}$ suspensi bakteri, dihomogenkan dan biarkan memadat. Setelah media padat, selanjutnya kertas cakram steril ditetesi dengan $10 \mu \mathrm{L}$ sediaan uji kemudian diinkubasi pada suhu $37^{\circ} \mathrm{C}$, selama \pm 24 jam. Diamati pertumbuhan bakteri dan diukur diameter daya hambat yang ditandai dengan adanya zona bening. Pengujian dilakukan terhadap ekstrak etanol buah kapulaga (Amomum compactum Sol. ex Maton) dengan konsentrasi 2, 4\% dan 6\%, sebagai kontrol negatif digunakan DMSO (Rasyadi et al, 2019a).

\section{Pengujian Aktivitas Antibakteri Sabun Mandi Cair Ekstrak Etanol Buah Kapulaga (Amomum compactum Sol. ex Maton)}

Sebanyak $10 \mathrm{~mL}$ medium MHA dimasukkan kedalam cawan petri ditambahkan 1 $\mathrm{mL}$ suspensi bakteri, dihomogenkan dan biarkan memadat. Setelah media padat, selanjutnya kertas cakram steril ditetesi dengan $10 \mu \mathrm{L}$ sediaan uji kemudian diinkubasi pada suhu $37 \circ C$, selama \pm 24 jam. Diamati pertumbuhan bakteri dan diukur diameter daya hambat yang ditandai dengan adanya zona bening. Pengujian dilakukan terhadap sediaan F0, F1, F2, F3 dan pembanding $D \circledR$ (Mawaddah and Fakhrurrazi, 2018; Rasyadi et al, 2019a).

\section{HASIL DAN PEMBAHASAN}

Pengujian aktivitas antibakteri ekstrak buah kapulaga dan sabun mandi cair ekstrak buah kapulaga terhadap bakteri Staphylococus aureus dilakukan menggunakan metode difusi agar. Metode ini dipilih karena pengerjaannya sederhana, mudah dan dapat dilakukan dengan mengukur diameter zona bening (clear zone). Clear zone tersebut merupakan petunjuk adanya respon hambatan pertumbuhan bakteri oleh suatu senyawa antibakteri dalam ekstrak (Sinurat et al., 2019).

Bakteri uji disuspensikan ke dalam larutan $\mathrm{NaCl}$ fisiologis $0,9 \%$ steril karena larutan $\mathrm{NaCl}$ fisiologis merupakan lingkungan yang isotonik bagi bakteri uji. Lalu suspensi dihomogenkan menggunakan vorteks dan diukur kekeruhannya (kepadatan jumlah sel bakteri) dengan membandingkan dengan standar kekeruhan Iarutan Mc.Farland 0,5\%. Pengukuran diameter daya hambat ekstrak buah kapulaga dilakukan dengan melarutkan masing-masing ekstrak dengan pelarut DMSO.

Berdasarkan tabel respon hambatan pertumbuhan bakteri, klasifikasi daya hambat dibagi menjadi empat kategori, yaitu kuat jika diameter zona bening $>20 \mathrm{~mm}$, sedang jika diameter zona bening 16 - $19 \mathrm{~mm}$, lemah jika diameter zona bening $10-15 \mathrm{~mm}$ dan tidak ada jika diameter zona bening $<10 \mathrm{~mm}$ (Greenwood, 1995).

Ekstrak etanol buah kapulaga dengan konsentrasi $2 \%$ memberikan diameter daya hambat rata - rata yaitu 16,67 mm yang termasuk golongan sedang, ekstrak buah kapulaga konsentrasi $4 \%$ memberikan diameter daya hambat rata - rata sebesar $17,87 \mathrm{~mm}$ yang termasuk golongan sedang, ekstrak buah kapulaga konsentrasi $6 \%$ memberikan diameter daya hambat rata - rata sebesar $20,10 \mathrm{~mm}$, diapat dilihat pada Gambar 1 dan Tabel 1.

Adanya aktivitas antibakteri sabun cair tersebut mungkin disebabkan oleh kandungan metabolit sekunder yang terkandung dalam buah kapulaga yakni saponin, flavonoid, terpenoid dan fenolik. Saponin dapat merusak integritas membran sel bakteri. Flavonoid dapat membunuh bakteri dengan cara melisiskan dinding sel bakteri dan menurunkan densitas sel bakteri. Terpenoid dapat melarutkan dinding sel bakteri dengan memperlemah jaringan membran (Sari and Ferdinan, 2017). Efek menghambat pertumbuhan bakteri juga diduga berhubungan dengan senyawa fenol yang terkandung di dalamnya. Mekanisme kerja fenolik sebagai antibakteri dengan cara menghambat transfer elektron pada rantai pernafasan mitokondria, mengganggu atau merusak komponen dinding sel yakni peptidoglikan, menonaktifkan enzimenzim esensial, perampasan mineral bakteri dan 
Tabel 1. Diameter Daya Hambat Ekstrak Etanol Buah Kapulaga dan Sabun Mandi Cair Ekstrak Etanol Buah Kapulaga

\begin{tabular}{cc}
\hline $\begin{array}{c}\text { Kelompok Ekstrak etanol } \\
\text { buah kapulaga }\end{array}$ & $\begin{array}{c}\text { Diameter daya hamb at } \\
\text { Rata }- \text { rata } \pm \text { SD }(\mathbf{m m})\end{array}$ \\
\hline C- & 0 \\
C1 & $16,67 \pm 0,35$ \\
C2 & $17,87 \pm 0,51$ \\
C3 & $20,10 \pm 0,72$ \\
\hline
\end{tabular}

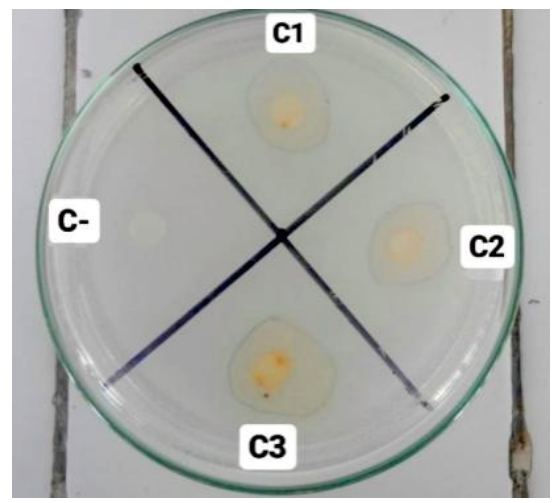

Keterangan:

C- : Kontrol negatif (DMSO)

C1 : Konsentrasi ekstrak buah kapulaga 2\%

C2 : Konsentrasi ekstrak buah kapulaga $4 \%$

C3 : Konsentrasi ekstrak buah kapulaga $6 \%$

\section{Gambar 1. Uji Aktivitas Antibakteri Ekstrak Etanol Buah Kapulaga Terhadap Bakteri Staphylococcus aureus}

mengganggu kerja membran sitoplasma yang akan menyebabkan terganggunya proses metabolisme bakteri yang akhirnya mengakibatkan kematian bakteri (Zalfiatri et al, 2018).

Hasil uji aktivitas antibakteri dari sediaan sabun mandi cair memberikan diameter daya hambat rata-rata pada masing - masing formula sabun mandi cair ekstrak buah kapulaga $\mathrm{FO}=$ 20,47 mm (kategori kuat), $F 1=22,33 \mathrm{~mm}$ (kategori kuat), F2 $=24,63 \mathrm{~mm}$ (kategori kuat), $\mathrm{F} 3=25,80 \mathrm{~mm}$ (kategori kuat) dan pada sabun mandi cair pembanding $D \circledast 20,20 \mathrm{~mm}$ (kategori kuat) dapat dilihat pada Gambar 2 dan Tabel 2.

Bila dibandingkan hasil uji aktivitas antibakteri antara ekstrak dan sabun mandi cair yang mengandung ekstrak, didapatkan bahwa daya hambat sabun mandi cair yang mengandung ekstrak lebih besar dari pada ekstrak. Hal tersebut disebabkan oleh adanya natrium lauryl sulfat yang berfungsi sebagai antibakteri (Rowe et al, 2009).

Semakin tinggi konsentrasi ekstrak buah kapulaga, semakin tinggi aktivitas daya hambat terhadap Staphylococcus aureus. Hal ini dapat terjadi mungkin karena sineol (minyak atsiri) yang terkandung dalam buah kapulaga juga dapat menghambat dan membunuh mikroorganisme dikaitkan dengan kemampuannya pada mikroorganisme yang bersifat hidrofobik. Hal ini

Tabel 2. Diameter Daya Hambat Sabun Mandi Cair Ekstrak Etanol Buah Kapulaga

\begin{tabular}{cc}
\hline $\begin{array}{c}\text { Kelompok Sabun Mandi Cair } \\
\text { Ekstrak Etanol Buah } \\
\text { Kapulaga }\end{array}$ & $\begin{array}{c}\text { Diameter daya hambat } \\
\text { Rata - rata } \pm \text { SD }(\mathbf{m m})\end{array}$ \\
\hline F0 & $20,47 \pm 0,40$ \\
F1 & $22,33 \pm 0,85$ \\
F2 & $24,63 \pm 0,58$ \\
F3 & $25,80 \pm 0,17$ \\
P & $20,20 \pm 0,17$ \\
\hline
\end{tabular}

Keterangan:

F0 : Sabun mandi cair mengandung ekstrak etanol buah kapulaga $0 \%$ (blanko)

$\mathrm{F} 1$ : Sabun mandi cair mengandung ekstrak etanol buah kapulaga $2 \%$

F2 : Sabun mandi cair mengandung ekstrak etanol buah kapulaga $4 \%$

F3 : Sabun mandi cair mengandung ekstrak etanol buah kapulaga $6 \%$

$P$ : Sediaan Sabun Mandi Cair sebagai Pembanding 


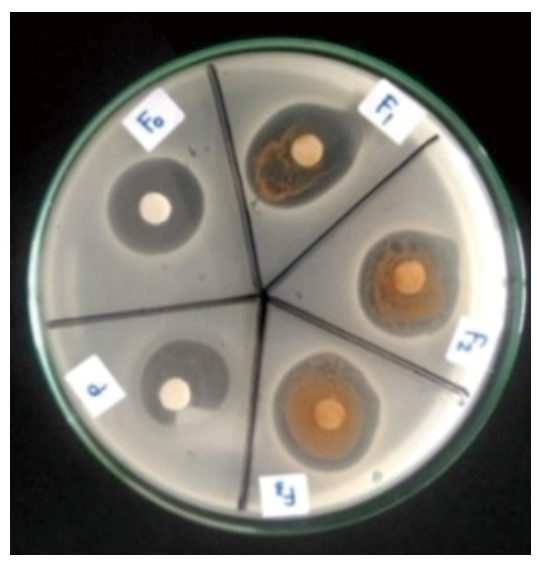

Gambar 2. Uji Aktivitas Antibakteri Sabun Mandi Cair Ekstrak Buah Kapulaga Terhadap Bakteri Staphylococcus aureus

menyebabkan minyak dipartisi pada membran sel lipid bilayer, yang akan mempengaruhi rantai pernapasan dan menyebabkan kebocoran isi sel bakteri. Kelemahan sistem enzim bakteri juga dapat menjadi mekanisme aksi yang potensial. Berbagai komponen minyak atsiri dapat meningkatkan permeabilitas sel bakteri dan meningkatkan penetrasi antibiotik (Ulya et al, 2019).

\section{KESIMPULAN}

Berdasarkan hasil uji daya aktivitas antibakteri dari sediaan sabun mandi cair memberikan diameter daya hambat rata-rata pada masing - masing formula sabun mandi cair ekstrak buah kapulaga F1 = 22,33 mm (kategori kuat), F2 = 24,63 mm (kategori kuat), F3 = 25,80 $\mathrm{mm}$ (kategori kuat). Dapat disimpulkan bahwa semua formula sabun mandi cair ekstrak etanol buah kapulaga memiliki aktivitas daya hambat terhadap Staphylococcus aureus dengan kategori kuat.

\section{DAFTAR PUSTAKA}

Aristyawan, A. D., Sugijanto, N. E. and Suciati, S. 2018. Potensi Antibakteri dari Ekstrak Etanol Spons Agelas cavernosa. Jurnal Farmasi Dan IImu Kefarmasian Indonesia, 4(1), pp. 39-43.

Budiarti, R., Djamil, R. and Kumala, S. 2013. Penetapan Parameter Farmakognosi Dan Uji Aktifitas Antibakteri Dari Ekstrak $\mathrm{Buah} \mathrm{Kapulaga} \mathrm{(A} \mathrm{momum}$ Cardamomum Willd.). Seminar Nasional LUSTRUM X Fakultas Farmasi Universitas Pancasila.

Deviarny, C., Friardi, F. and Rissa, M. M. 2015. Pengaruh Konsentrasi Gelatin dalam Formulasi Permen Jeli Penghilang Bau Mulut dari Minyak Atsiri Buah Kapulaga (Amomum compactumsol. Ex Maton.
Scientia : Jurnal Farmasi dan Kesehatan, 5(2), pp. 103-107.

Dimpudus, S. A., Yamlean, Y. V. P. and Yudistira, A. 2017. Formulasi Sediaan Sabun Cair Antiseptik Ekstrak Etanol Bunga Pacar Air (Impatiens balsamina L.) dan Uji Efektifitasnya terhadap Bakteti Staphylococcus aureus secara In Vitro. PHARMACON, 6(3), pp. 208-215.

Greenwood .1995. Antibiotics Susceptibility (Sensitivity) Test, Antimicrobial Ant Chemoterapy. San Fransisco: Addison Westley Longman Inc.

Kalangi, S. J. R. 2014. Histofisiologi Kulit. Jurnal Biomedik(JBM), 5(3), pp. S12-S20.

Komala, O., Ismanto and Maulana, M. A. 2020. Antibacterial Activity Of Java Cardamom Seed Extract ( Amomum Compactum Soland. Ex Maton) Against Streptococcus pyogenes. Ekologia : Jurnal IImiah IImu Dasar dan Lingkungan Hidup, 20(1), pp. 31-39..

Mawaddah, N. and Fakhrurrazi, R. 2018. Aktivitas Antibakteri Ekstrak Tempe Terhadap Bakteri Staphylococcus aureus. Jimvet, 2(3), pp. 230-241.

Putra, R. M., Fahrurroji, A. and Wijianto, B. 2016. Optimasi Formulasi Sabun Mandi Cair Ekstrak Etanol Rimpang Jahe Merah (Zingiber Officinale Rosc. Var Rubrum) Dengan Metode Simplex Lattice Design. Jurnal Teknosains, 5(2), pp. 111-116.

Putri, S. D. K., Susilowati, A. And Setyaningsih, R. 2017. In vitro testing of antibacterial activity of extracts of seed cardamom (Amomum compactum) against by Aeromonas hydrophila. Biofarmasi Journal of Natural Product Biochemistry, 14(1), pp. 10-18.

Rasyadi, Y., Rahim, F. and Putri, D. E. 2019a. Uji Aktivitas Antibakteri Sediaan Kumur (Mouthwash) Dari Ekstrak Daun Sukun Artocarpus altilis (Parkinson Ex F.A.Zorn) Fosberg Terhadap Pertumbuhan Bakteri Streptococcus mutans. Scientia : Jurnal Farmasi dan Kesehatan, 9(1), pp. 24-28.

Rasyadi, Y., Yenti, R. and Jasril, A. P. 2019b. Formulasi dan Uji Stabilitas Fisik Sabun Mandi Cair Ekstrak Etanol Buah Kapulaga (Amomum compactum Sol. ex Maton). PHARMACY: Jurnal Farmasi Indonesia (Pharmaceutical Journal of Indonesia), 16(2), pp. 188-198.

Rosalina, D., Martodihardjo, S. and Listiawan, M. Y. 2010. Staphylococcus aureus sebagai Penyebab Tersering Infeksi Sekunder pada Semua Erosi Kulit Dermatosis Vesikobulosa. Berkala IImu Kesehatan Kulit dan Kelamin, 2(318), pp. 102-108.

Rowe, R., Sheskey, P. and Quinn, M. 2009. 
Handbook Of Pharmaceutical Excipients. Journal, 3(2), pp. 57-68. Lexi-Comp: American Pharmaceutical Association, Inc. Washington DC. pp. 651

Ryan, KJ, Champoux JJ, Falkow S, Plonde JJ, Drew WL, Neidhardt FC, \& Roy CG. 1994. Medical Microbiology An Introduction To Infectious Diseases. 3rd Ed. Connecticut: Appleton \& Lange. pp. 254

Sari, R. and Ferdinan, A. 2017. Antibacterial Activity Assay of the Liquid Soap from the Extract of Aloe vera Leaf Peel. Pharmaceutical Sciences and Research, 4(3), pp. 111-120.

Sinurat, A. A. P. Renta, P. P., Herliany, N. E., Negara, B.F.S.P., Purnama, D. 2019. Uji Aktivitas Antibakteri Ekstrak Metanol Rumput Laut Gracilaria edulis Terhadap Bakteri Aeromonas hydrophila. Jurnal Enggano, 4(1), pp. 105-114.

Sukandar, D. Hermanto, S., Amelia, E. R., Zaenudin, M. 2016. Aktivitas Antibakteri Ekstrak Biji Kapulaga (Amomum compactum Sol. Ex Maton). Jurnal Kimia Terapan Indonesia, 17(2), pp. 119-129.

Sukawaty, Y., Warnida, H. and Artha, A. V. 2016. Formulasi Sediaan Sabun Mandi Padat Ekstrak Etanol Umbi Bawang Tiwai (Eleutherine bulbosa (Mill.) Urb.). Media Farmasi,13(1), pp. 14-22.

Ulya, M., Orienty, F. N. and Hayati, M. 2019. Efek Uji Daya Bunuh Ekstrak Kulit Buah Jeruk Nipis (Citrus Auranti Folia) Terhadap Bakteri Streptococcus mutans. B-Dent, Jurnal Kedokteran Gigi Universitas Baiturrahmah, 5(1), pp. 30-37.

Utomo, S. B. Fujiyanti, M., Lestari, W. P. Mulyani, S. 2018. Antibacterial Activity Test of the C-4-methoxyphenylcalix[4]resorcinarene C o m p o u n d M o d i fi e d b y Hexadecyltrimethylammonium-Bromide against Staphylococcus aureus and Escherichia coli Bacteria. JKPK (Jurnal Kimia dan Pendidikan Kimia), 3(3), pp. 201-209.

Widyasanti, A., Farddani, C. and Rohdiana, D. 2016. Pembuatan Sabun Padat Transparan Menggunakan Minyak Kelapa Sawit (Palm Oil) Dengan Penambahan Bahan Aktif Ekstrak Teh Putih (Camellia sinensis). Jurnal Teknik Pertanian Lampung, 5(3), pp. 125-136.

Yulianti, R., Nugraha, D. A. and Nurdianti, L. 2015. Formulasi Sediaan Sabun Mandi Cair Ekstrak Daun Kumis Kucing (Orthosiphon aristatus (BI) Miq.). Kartika Jurnal Ilmiah Farmasi, 3(2), pp. 1-11.

Zalfiatri, Y., Hamzah, F. and Simbolon, M. T. 2018. Pembuatan Sabun Transparan Dengan Penambahan Ekstrak Batang Pepaya Sebagai Antibakteri. Chempublish 